\title{
Temperature dependence of planktonic metabolism in the subtropical North Atlantic Ocean
}

\author{
L. S. García-Corral ${ }^{1}$, E. Barber ${ }^{1}$, A. Regaudie-de-Gioux ${ }^{7}$, S. Sal ${ }^{2}$, J. M. Holding ${ }^{1}$, S. Agustí ${ }^{1,3}$, N. Navarro ${ }^{4}$ P. Serret $^{5}$, \\ P. Mozetič ${ }^{6}$, and C. M. Duarte ${ }^{1,3}$ \\ ${ }^{1}$ Department of Global Change Research, IMEDEA (CSIC-UIB) Instituto Mediterráneo de Estudios Avanzados , Miquel \\ Marqués 21, 07190 Esporles, Spain \\ ${ }^{2}$ Centro Oceanográfico de Gijón, Instituto Español de Oceanografia, Avenida Principe de Asturias, 70 bis, 33212 Gijón, Spain \\ ${ }^{3}$ The UWA Oceans Institute and School of Plant Biology, University of Western Australia, 35 Stirling Highway, Crawley \\ 6009, Australia \\ ${ }^{4}$ Área de Biodiversidad y Conservación ESCET, Universidad Rey Juan Carlos, Tulipán s/n, Móstoles, 28933 Madrid, Spain \\ ${ }^{5}$ Departamento de Ecología y Biología Animal, Universidad de Vigo, 36200, Spain \\ ${ }^{6}$ National Institute of Biology, Marine Biology Station, Fornace 41, 6330 Piran, Slovenia \\ ${ }^{7}$ Laboratório Aquarela, Centro de Biologia Marinha da Universidade de São Paulo (CEBIMAR), Rodovia Manoel Hypólito \\ do Rego, Km 131.5 Praia do Cabelo Gordo, São Sebastião 11600-000, SP, Brazil
}

Correspondence to: L. S. García-Corral (lgarcia@imedea.uib-csic.es)

Received: 22 January 2014 - Published in Biogeosciences Discuss.: 26 February 2014

Revised: 27 June 2014 - Accepted: 21 July 2014 - Published: 27 August 2014

\begin{abstract}
The temperature dependence of planktonic metabolism in the subtropical North Atlantic Ocean was assessed on the basis of measurements of gross primary production (GPP), community respiration (CR) and net community production (NCP), as well as experimental assessments of the response of $\mathrm{CR}$ to temperature manipulations. Metabolic rates were measured at 68 stations along three consecutive longitudinal transects completed during the Malaspina 2010 Expedition, in three different seasons. Temperature gradients were observed in depth and at basin and seasonal scale. The results showed seasonal variability in the metabolic rates, the highest rates being observed during the spring transect. The overall mean integrated GPP / CR ratio was $1.39 \pm 0.27$ decreasing from winter to summer, and the NCP for the subtropical North Atlantic Ocean during the cruises exhibits net autotrophy $(\mathrm{NCP}>0)$ in about twothirds $(66 \%)$ of the total sampled communities. Also, we reported the activation energies describing the temperature dependence of planktonic community metabolism, which was generally higher for CR than for GPP in the subtropical North Atlantic Ocean, as the metabolic theory of ecology predicts. Furthermore, we made a comparison of activation energies describing the responses to in situ temperature in the field
\end{abstract}

$\left(\mathrm{Ea}_{\mathrm{CR}}=1.64 \pm 0.36 \mathrm{eV}\right)$ and those derived experimentally by temperature manipulations $\left(\mathrm{Ea}_{\mathrm{CR}}=1.45 \pm 0.6 \mathrm{eV}\right)$, which showed great consistency.

\section{Introduction}

The metabolic status of plankton communities is a fundamental property controlling the role of plankton communities in the ocean's carbon budget (Duarte et al., 2011, 2013). In particular, net community production (NCP), the difference between gross primary production (GPP) and community respiration $(\mathrm{CR})$, determines whether plankton communities act as $\mathrm{CO}_{2}$ sinks (autotrophic communities, $\mathrm{NCP}>0$ ) or $\mathrm{CO}_{2}$ sources (heterotrophic communities, $\mathrm{NCP}<0$ ).

Recent analyses suggest that seawater temperature is a driver of plankton community metabolism (Regaudie-deGioux and Duarte, 2012), consistent with the metabolic theory of ecology (MTE, Gillooly et al., 2001; Brown et al., 2004), which predicts that both GPP and CR should increase with increasing temperature. MTE also expects that the activation energy (Ea) for respiration should be higher than for photosynthesis (Harris et al., 2006), as confirmed by 
observations (López-Urrutia et al., 2006; Regaudie-de-Gioux and Duarte, 2012). Hence, plankton respiration rates are expected to increase faster with ocean warming than production rates. Consequently, ocean warming should lead to a weakening of the $\mathrm{CO}_{2}$ uptake by ocean biota, and may lead to a possible positive feedback in the carbon global budget (Duarte et al., 2012, 2013).

Resolving the temperature dependence of planktonic community metabolism is fundamental to predict the future role of plankton in the carbon budget of a warmer ocean. However, research on ocean planktonic community metabolism is still limited spatially and temporally, with measurements focused on restricted areas such as the NE Atlantic Ocean, the eastern Arctic Ocean, the Southern Ocean and the Mediterranean Sea (Robinson and Williams, 2005; Regaudie-deGioux and Duarte, 2013). Even in the North Atlantic Basin, the most intensively studied area of the world's ocean, there is a paucity of estimates of net community metabolism in the western basin.

The North Atlantic Ocean plays an important role as a sink of atmospheric $\mathrm{CO}_{2}$ (Sabine et al., 2004). However, it has been warming since the 1950s and its heat content has been increasing faster than the mean ocean rate $\left(0.3 \mathrm{~W} \mathrm{~m}^{-2}\right)$, exceeding $8.0 \mathrm{~W} \mathrm{~m}^{-2}$ in the midlatitudes of the northwestern basin (Levitus et al., 2000, 2005). In addition, the subtropical North Atlantic Ocean shows a strong longitudinal and latitudinal temperature gradient, increasing from northwest Africa to northeast America, mainly due to influence from the Gulf Stream and North Atlantic Current (Marshall et al., 2001). This temperature gradient suggests that metabolic rates may vary spatially and that the current warming trend may affect planktonic communities differentially in the western and eastern basins of the North Atlantic Ocean, which experience different thermal regimes.

Here we assess the seasonal and regional variability of plankton metabolic rates in the subtropical North Atlantic Ocean. We do so on the basis of near-zonal cruises conducted along three seasons (Leg 1 in winter, Leg 2 in spring and Leg 3 during summer) in 2011. We also assess the thermal control on plankton metabolic rates, based on the in situ incubations and experimental temperature manipulations to examine the temperature dependence of community respiration rates.

\section{Materials and methods}

\subsection{Sampling site and study area}

The study was conducted in the framework of the Malaspina 2010 Expedition, a circumnavigation project that included three zonal cruises along the subtropical North Atlantic Ocean, encompassing a latitudinal range spanning from $12.4^{\circ} \mathrm{N}$ to $41.6^{\circ} \mathrm{N}$ and a large longitudinal variation from $-79.2^{\circ} \mathrm{E}$ to $-14.7^{\circ} \mathrm{E}$ (Fig. 1). The first cruise (Leg 1) was conducted on board Spanish R/V Sarmiento de Gamboa,

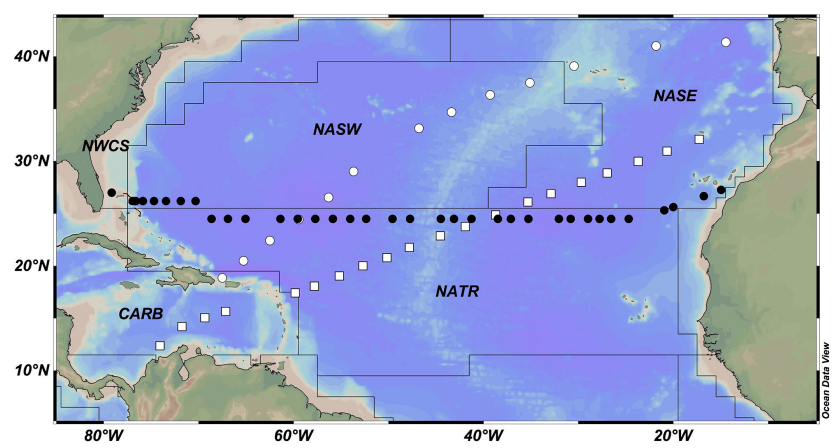

Figure 1. Map showing the stations occupied in Leg 1-winter (black circles), Leg 2-spring (white circles) and Leg 3-summer (white squares) during the Malaspina 2010 Expedition and the Longhurst Provinces crossed in the study.

sailing from the Canary Islands (Spain) to Florida (USA) along the $24^{\circ} \mathrm{N}$ parallel between 28 January and 9 March 2011, during the winter season. The second cruise (Leg 2) was also conducted on board Spanish R/V Sarmiento de Gamboa, which sailed from Santo Domingo (Dominican Republic) to Vigo (Spain) from 23 March to 8 April, during spring of 2011. The third and last cruise (Leg 3) was carried out on board Spanish R/V Hespérides sailing from Cartagena de Indias (Colombia) to Cartagena (Spain) during the summer of 2011, between 20 June and 10 July.

The three cruises included stations within five of the different biogeographical provinces described by Longhurst (Longhurst, 1998, 2007). Sampled stations were mostly concentrated in 3 provinces: the North Atlantic Subtropical Gyre Province East (NASE or NAST-E), including 4 stations in winter, 3 in spring and 7 in summer; the North Atlantic Subtropical Gyre Province West (NASW) with 7 stations in winter and 6 in spring; and the North Atlantic Tropical Gyre Province (NATR), with 23 stations in winter, 3 in spring and 8 stations in summer. The data set also included stations in the Caribbean Province (CARB) with one station in spring and five during summer; only one station was sampled within the North West Coastal Atlantic Shelves Province (NWCS) during the winter cruise (Table 3, Fig. 2).

Total concentration of chlorophyll $a(\mathrm{Chl} a)$, for spring and summer cruises was determined fluorometrically (following Yentsch and Menzel, 1963) by acetone extraction of chlorophyll $a$ on the cells retained in GF/F filters after filtering 200 $500 \mathrm{~mL}$ samples (Estrada, 2012). Chlorophyll $a$ on cruise 1 in the winter was estimated from calibrated CTD fluorescence data $\left(R^{2}=0.92, p<0.001\right)$.

\subsection{Community metabolism}

Metabolic rates of the planktonic communities were measured at 35, 13 and 20 stations in Leg 1 (winter), Leg 2 (spring) and Leg 3 (summer), respectively, yielding a total of 68 stations (Fig. 1). During the three cruises seawater was 
sampled at three different depths within the photic layer: the deep chlorophyll maximum (DCM, 114.1 $\pm 4.1 \mathrm{~m}$ ), which receives, on average, $1 \%$ of the incident irradiance; surface waters $(4.5 \pm 2.5 \mathrm{~m})$; and an intermediate depth $(43.1 \pm 2.5 \mathrm{~m})$ between surface and DCM, receiving $20 \%$ of the incident radiation on the surface. Both DCM and intermediate depths were sampled using a Rosette sampler system fitted with a calibrated Sea-Bird SBE 9 CTD and 12L Niskin bottles. Surface waters were sampled manually with a 30 L Niskin bottle during summer and with a Rosette sampler system in winter and spring. All seawater samples were directly siphoned from Niskin bottles into calibrated $100 \mathrm{~mL}$ borosilicate glass narrow-mouth Winkler bottles using a silicon tube.

For each depth, seven replicates were fixed (biological activity immediately stopped), to provide the initial oxygen concentration. The two other sets of seven replicates, dark and transparent, were filled and incubated for $24 \mathrm{~h}$. The surface communities were incubated on deck for $24 \mathrm{~h}$ in a large 2000 liter tank with continuous circulation of surface seawater to maintain the temperature of the surface waters and natural solar radiation. Bottles were covered with neutral screens to reduce incident radiation by $20 \%$, in addition to the 8 to $12 \%$ reduction in photosynthetically active radiation transmittance by the bottles themselves (Agustí et al., 2014). The light conditions experienced by the incubated communities mimic those in the upper layer of the ocean but represent only an approximation, as the changes in the light environment due to mixing were not reproduced. For intermediate and DCM depths, the dark and transparent bottles were placed inside opaque PVC and transparent polycarbonate incubation cylinders, respectively. Transparent incubation tubes were fitted with a combination of neutral density (LEE 210) and blue (HT061 Mist, 62.4\% transmission) filters to simulate the irradiance levels experienced by the community at their original sampling depth. Incubation tubes were filled with surface seawater and connected to a closed circuit pump incubator with a temperature control, holding the temperature within $\pm 0.5^{\circ} \mathrm{C}$ of the in situ temperature and set according to the temperature profile retrieved from the CTD cast. At the end of the incubation period, light and dark bottles from each depth were fixed to determine final $\mathrm{O}_{2}$ concentrations.

Planktonic metabolism was evaluated from changes in dissolved oxygen concentrations, which were determined by automated high-precision Winkler titration with a potentiometric end-point Metrohm 808 Titrando (Oudot et al., 1988). CR and NCP were calculated from changes in dissolved oxygen concentrations, before and after incubation of samples under "dark" and "light" conditions, respectively, and GPP was calculated as NCP + CR. We used $0.01 \mathrm{~N}(\mathrm{SD} \pm 0.000141)$ thiosulfate solution and the reagents recommended by Carrit and Carpenter (1966).

Volumetric metabolic rate estimates (GPP, CR and NCP) for the three different cruises were tested for normality before statistical analysis via Shapiro-Wilk tests with a 0.05 signif- icance level, and homogeneity of variances was tested using the Levene test. When GPP, CR and NCP estimates deviated from a normal distribution $(p>0.05)$, a Kruskal-Wallis test was used to compare variables. The Kruskal-Wallis test is a non-parametric equivalent to a one-way analysis of variance by ranks. It tests the null hypothesis that three or more groups all come from the same distribution. It uses the ranks of data and is therefore resistant to outliers. Metabolic rates are expressed as $\mathrm{mmol} \mathrm{O}_{2} \mathrm{~m}^{-3} \mathrm{~d}^{-1}$ and specific metabolic rates as $\mathrm{mmol} \mathrm{O}_{2} \mathrm{mg} \mathrm{Chl} a^{-1} \mathrm{~d}^{-1}$.

Integrated metabolic rates were calculated by adding up the weighted-average rate between consecutive sampling depths, from the surface layer to the DCM (1\% PAR) and standard errors were calculated using error propagation. Because the depth of integration differed, for comparisons we used the depth-averaged rate, calculated as the ratio between the mean integrated rate and the depth of integration.

\subsection{Experimental assessment of the temperature dependence of community respiration rates}

During the spring, we performed experimental temperature manipulations at each of the 13 sampled stations to test the response of planktonic CR rates to temperature increase. Seawater was sampled from $10 \mathrm{~m}$ above the DCM and incubated at different temperatures. At this depth (10 $\mathrm{m}$ above DCM) plankton communities receive more light than at the DCM (Teira et al., 2005), but experience almost the same physical and chemical conditions, so production and biomass are expected to be close to the highest values in the water column. The chlorophyll maximum is somewhat deeper than the depth of maximum photosynthetic rate and of the biomass maximum for photosynthetic cells. In the Atlantic Ocean the DCM is generally not a biomass maximum but rather the result of a decrease of the carbon to chlorophyll $a$ ratio with depth (Marañón et al., 2000). Seawater was siphoned into calibrated dark $100 \mathrm{~mL}$ Winkler bottles and incubated into opaque PVC tubes to protect them from light. Seven initial replicates were used to determine the initial oxygen concentration, and a set of seven replicates each were incubated in different temperature treatments. We mimicked four temperatures of the in situ profiles: (1) in situ temperature at $10 \mathrm{~m}$ above DCM depth $(81 \pm 6 \mathrm{~m})$, (2) a temperature corresponding to the intermediate depth $(45 \pm 2.5 \mathrm{~m})$, (3) surface (5$6 \mathrm{~m}$ ) temperature, and (4) $3{ }^{\circ} \mathrm{C}$ above surface temperature. The resulting range of the experimental temperatures for incubations varied between 3 and $7^{\circ} \mathrm{C}$ across the experiments performed. Experimental bottles were incubated for $24 \mathrm{~h}$ as indicated above and the $\mathrm{CR}$ rates were determined following the same methodology as outlined above.

Whereas the experimental assessments use the same community, the evaluation of the temperature dependence of metabolic rates across stations is confounded by the changes in community. Indeed, previous examinations of 
Table 1. Mean $( \pm \mathrm{SE})$ temperature $\left({ }^{\circ} \mathrm{C}\right)$ and chlorophyll $a\left(\mathrm{mg} \mathrm{Chl} a \mathrm{~m}^{-3}\right)$ for the three sampled depths in Leg 1-winter, Leg 2-spring and Leg 3-summer.

\begin{tabular}{|c|c|c|c|c|c|c|c|c|c|c|}
\hline & & \multicolumn{3}{|c|}{ Winter (leg 1) } & \multicolumn{3}{|c|}{ Spring (leg 2) } & \multicolumn{3}{|c|}{ Summer (leg 3) } \\
\hline & & Surface & $20 \%$ PAR & $\mathrm{DCM}$ & Surface & $20 \%$ PAR & DCM & Surface & $20 \%$ PAR & DCM \\
\hline $\begin{array}{l}\text { Temperature } \\
\left({ }^{\circ} \mathrm{C}\right)\end{array}$ & $\begin{array}{l}\text { Mean } \pm \mathrm{SE} \\
\text { Range } \\
N \\
\text { Mean Leg } \pm \mathrm{SE}\end{array}$ & $\begin{array}{l}23.0 \pm 0.17 \\
20.6-24.8 \\
35\end{array}$ & $\begin{array}{l}23.0 \pm 0.17 \\
20.6-24.8 \\
32 \\
22 \pm 0.13\end{array}$ & $\begin{array}{l}21.3 \pm 0.21 \\
19.3-24.3 \\
34\end{array}$ & $\begin{array}{l}19.9 \pm 1.15 \\
14.7-25.4 \\
13\end{array}$ & $\begin{array}{l}19.7 \pm 1.12 \\
14.7-25.7 \\
13 \\
19.5 \pm 0.62\end{array}$ & $\begin{array}{l}18.8 \pm 0.99 \\
14.3-24.8 \\
12\end{array}$ & $\begin{array}{l}25.8 \pm 0.64 \\
20.9-29.1 \\
20\end{array}$ & $\begin{array}{l}25.2 \pm 0.70 \\
20.8-29.1 \\
19 \\
24.5 \pm 0.42\end{array}$ & $\begin{array}{l}22.4 \pm 0.66 \\
17.4-27.4 \\
19\end{array}$ \\
\hline $\begin{array}{l}\text { Chlorophyll } a \\
\left(\mathrm{mg} \mathrm{m}^{-3}\right)\end{array}$ & $\begin{array}{l}\text { Mean } \pm \mathrm{SE} \\
\text { Range } \\
N \\
\text { Mean Leg } \pm \mathrm{SE}\end{array}$ & $\begin{array}{l}0.13 \pm 0.01 \\
0.08-0.23 \\
35\end{array}$ & $\begin{array}{l}0.15 \pm 0.01 \\
0.10-0.25 \\
32 \\
0.2 \pm 0.01\end{array}$ & $\begin{array}{l}0.30 \pm 0.02 \\
0.14-0.51 \\
34\end{array}$ & $\begin{array}{l}0.35 \pm 0.14 \\
0.02-1.63 \\
11\end{array}$ & $\begin{array}{l}0.31 \pm 0.12 \\
0.03-1.56 \\
12 \\
0.30 \pm 0.07\end{array}$ & $\begin{array}{l}0.25 \pm 0.10 \\
0.03-1.32 \\
12\end{array}$ & $\begin{array}{l}0.1 \pm 0.02 \\
0.04-0.31 \\
20\end{array}$ & $\begin{array}{l}0.09 \pm 0.01 \\
0.05-0.21 \\
20 \\
0.21 \pm 0.02\end{array}$ & $\begin{array}{l}0.43 \pm 0.03 \\
0.22-0.77 \\
20\end{array}$ \\
\hline
\end{tabular}

the temperature dependence of metabolic rates have demonstrated that bulk rates (i.e., $\mathrm{mmol}_{2} \mathrm{~m}^{-3} \mathrm{~d}^{-1}$ ) are dependent on both community biomass and temperature, with the biomass-specific rate being the component that is temperature dependent and conforming to the temperature dependence expected by the Arrhenius law and metabolic theory (e.g., Regaudie-de-Gioux and Duarte, 2012). Metabolic theory states that metabolic rates are a function of biomass and temperature (Brown et al., 2004), whereas biomass is not necessarily temperature dependence, so that use of bulk rates conceals the role of temperature. Moreover, previous research on the temperature dependence of metabolic rates shows that the most effective metric to standardize for community biomass is chlorophyll $a$ concentration both for GPP and CR (Regaudie-de-Gioux and Duarte, 2012).

Hence, we standardized the rates per unit chlorophyll $a$ to allow for cross-station comparison of temperature-dependent metabolism and comparisons of experimental assessments with previous assessments.

The activation energy (Ea) was derived from the slope of the Arrhenius plot, which shows the relationship of the natural logarithm of $\mathrm{Chl} a$-standardized $\mathrm{CR}_{\mathrm{Chl} a}$ and $\mathrm{GPP}_{\mathrm{Chl} a}$ rates $\left(\mathrm{mmol} \mathrm{O}_{2} \mathrm{mg} \mathrm{Chl} a^{-1} \mathrm{~d}^{-1}\right)$ with the inverted water temperature $(1 / k T)$ where $k$ is the Boltzmann's constant $\left(8.617734 \times 10^{-5} \mathrm{eV} \mathrm{K}^{-1}\right)$ and $T$ is the temperature in Kelvin degrees $\left({ }^{\circ} \mathrm{K}\right)$ (Gillooly et al., 2001; Brown et al., 2004).

\subsection{Satellite images}

Satellite images were retrieved from the AQUA MODIS (or Moderate Resolution Imaging Spectroradiometer) satellite. In order to make a unique map for each cruise, images of chlorophyll $a$ and surface water temperature were created using an average of 8 days from the central day station of the cruise (i.e, Leg 1 (winter): central date was 19/02/2011 and the average image was from 18/02/2011 to $25 / 02 / 2011$ ). The information was processed with the SeaDAS software and maps were created using ArcGis software by Esri.

\section{Results}

All three cruises were characterized by a gradient of cooler waters in the eastern basin to warmer waters in the western basin (Figs. 2a and 3b). Seasonal temperature differences were also significant (Kruskal-Wallis test, $p<0.0001$ ) with mean temperature $( \pm \mathrm{SE})$ of $22.4 \pm 0.13^{\circ} \mathrm{C}$ during the Northern Hemisphere winter, $19.5 \pm 0.6^{\circ} \mathrm{C}$ during spring (where stations were at generally higher latitudes) and warmer temperatures $\left(24.4 \pm 0.4^{\circ} \mathrm{C}\right)$ during summer. The seawater temperature also declined by about $1.7^{\circ} \mathrm{C}$ (winter), $1.1^{\circ} \mathrm{C}$ (spring), and $3.7^{\circ} \mathrm{C}$ (summer) from the surface to the DCM depth (Table 1, Fig. 2a). The deep chlorophyll maximum depth $\left(Z_{\mathrm{DCM}}\right)$, varied greatly from a minimum of $20 \mathrm{~m}$ in spring to a maximum of $165 \mathrm{~m}$ in winter, with a mean value of $114 \pm 4 \mathrm{~m}$ for all stations (Table 2, Fig. 2b).

Chlorophyll $a$ concentrations showed temporal and spatial variations. The mean $( \pm \mathrm{SE})$ chlorophyll $a$ concentration was similar in winter and summer $(0.20 \pm 0.01$ and $\quad 0.21 \pm 0.02 \mathrm{mgChl} a \mathrm{~m}^{-3}, \quad$ respectively), but higher concentrations were measured during spring $\left(0.30 \pm 0.07 \mathrm{mg} \mathrm{Chl} a \mathrm{~m}^{-3}\right)$. This difference is due to the maximum value of chlorophyll $a$ measured at the eastern basin in surface waters $\left(1.63 \mathrm{mgChl} a \mathrm{~m}^{-3}\right.$, Table 1 , Fig. 2b). The satellite imagery revealed a region of high chlorophyll $a$ concentrations in the eastern basin, affected by the northwest African upwelling (Fig. 3a). Most of the stations were occupied within the highly oligotrophic waters of the subtropical gyre, except for the northern stations in the eastern basin during spring, which extended to more productive waters (Figs. 2b and 3a). Chlorophyll $a$ concentrations decreased significantly with seawater temperature $\left(R^{2}=0.19, \quad p<0.0001, N=194\right)$ and increased with depth from surface waters to DCM depths in winter and summer. In spring, higher chlorophyll $a$ concentrations were found in surface and $20 \%$ PAR depths than at the DCM (Table 1, Fig. 2b), which indicates a fluorescence instead of a chlorophyll maximum.

Sea surface salinity showed significant differences (Kruskal-Wallis test, $p<0.0001$ ), between seasons, with lower values during spring (mean $\pm \mathrm{SE} ; 36.5 \pm 0.06$ ) and 


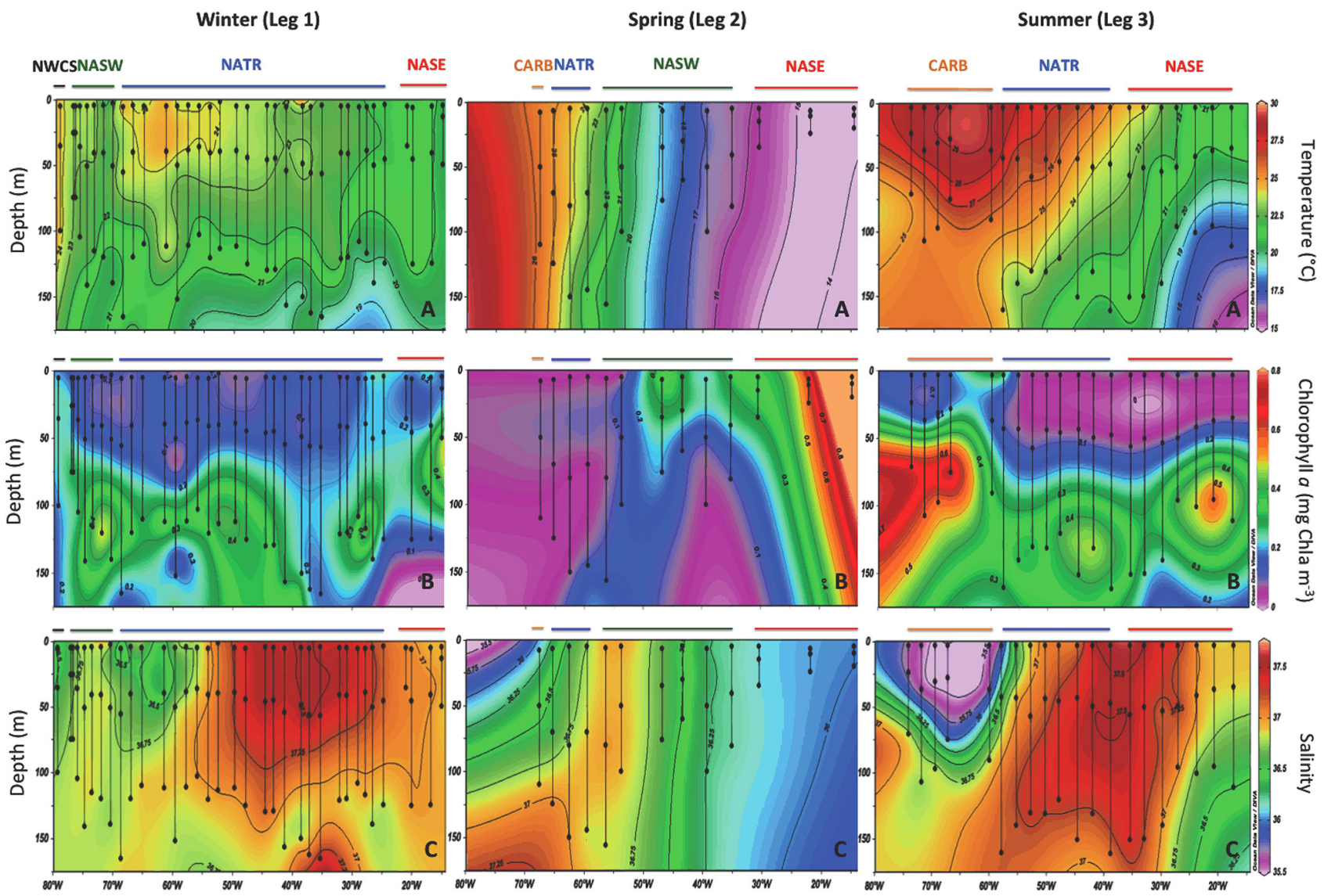

Figure 2. Contour plots for (a) temperature $\left({ }^{\circ} \mathrm{C}\right)$, (b) chlorophyll $a\left(\mathrm{mg} \mathrm{Chl} a \mathrm{~m}^{-3}\right)$ and (c) salinity of the profiles sampled (black lines) in Leg 1-winter, Leg 2-spring and Leg 3-summer. Black points indicated the three sampled depths (surface, $20 \%$ PAR and DCM) in each station.

higher values during summer $(36.8 \pm 0.08)$ and winter $(37 \pm 0.03)$. The lowest value was found at the Caribbean Province $(35.9 \pm 0.13)$, probably due to equatorial water that carries a summer seasonal Amazon signal (Dessier and Donguy, 1994), while the high evaporation and lack of riverine inputs close to the NATR Province resulted in higher salinity $(37 \pm 0.03)$ for the open ocean region (Fig. 2c).

The overall mean $( \pm \mathrm{SE})$ of volumetric $\mathrm{CR}$ rate for the study area was $1.70 \pm 0.23 \mathrm{mmol} \mathrm{O}_{2} \mathrm{~m}^{-3} \mathrm{~d}^{-1}$. CR rates showed a minimum during winter and summer in deep and cold waters $\left(0.01 \pm 0.27 \mathrm{mmol} \mathrm{O}_{2} \mathrm{~m}^{-3} \mathrm{~d}^{-1}\right.$ at $103 \mathrm{~m}, 21.5^{\circ} \mathrm{C}$ and $0.01 \pm 0.15 \mathrm{mmol} \mathrm{O}_{2} \mathrm{~m}^{-3} \mathrm{~d}^{-1}$ at $100 \mathrm{~m}, 18^{\circ} \mathrm{C}$, respectively) and a maximum during summer in the Caribbean shallower and warmer waters $\left(28.42 \pm 0.11 \mathrm{mmol} \mathrm{O}_{2} \mathrm{~m}^{-3} \mathrm{~d}^{-1}\right.$ at $23.5 \mathrm{~m}, 28^{\circ} \mathrm{C}$ ). Mean volumetric CR rates were lower during winter at the three sampled depths, and higher rates were observed during spring and summer cruises (Fig. 6a).

The overall mean $( \pm \mathrm{SE})$ volumetric GPP rate for the study area was $1.42 \pm 0.16 \mathrm{mmol} \mathrm{O}_{2} \mathrm{~m}^{-3} \mathrm{~d}^{-1}$. GPP followed similar patterns as CR, varying from below detection limit during the winter and summer cruises in surface waters to a maximum value of $18.01 \pm 0.11 \mathrm{mmol} \mathrm{O}_{2} \mathrm{~m}^{-3} \mathrm{~d}^{-1}$ in the warmest Caribbean waters during summer. The highest mean GPP rates were measured during spring at the three sampled depths (Fig. 6b).

The overall mean $( \pm \mathrm{SE}) \mathrm{NCP}$ rate was positive, indicative of autotrophic planktonic metabolism across seasons $\left(0.19 \pm 0.24 \mathrm{mmol} \mathrm{O}_{2} \mathrm{~m}^{-3} \mathrm{~d}^{-1}\right)$. NCP did not differ significantly among cruises (Kruskal-Wallis test, $p>0.05$ ), whereas CR and GPP were significantly higher for the spring cruise (Kruskal-Wallis test, $p<0.0001$ ). NCP did, however, show contrasting vertical patterns in each season. The communities sampled during winter were net autotrophic $(\mathrm{NCP}>0)$ from surface to DCM. During spring, autotrophic communities prevailed in the surface and $20 \%$ PAR layers and heterotrophic communities dominated at the deepest depths, while summer showed the reverse pattern (Fig. 6c).

The mean integrated GPP rate in spring was 3.8-fold higher than in summer and 2-fold higher than in winter. The minimum measured value was observed in winter, while the maximum was measured during the spring cruise. This pattern was also observed for CR mean integrated rates. The highest mean integrated $\mathrm{CR}$ rate was found in spring and 
A

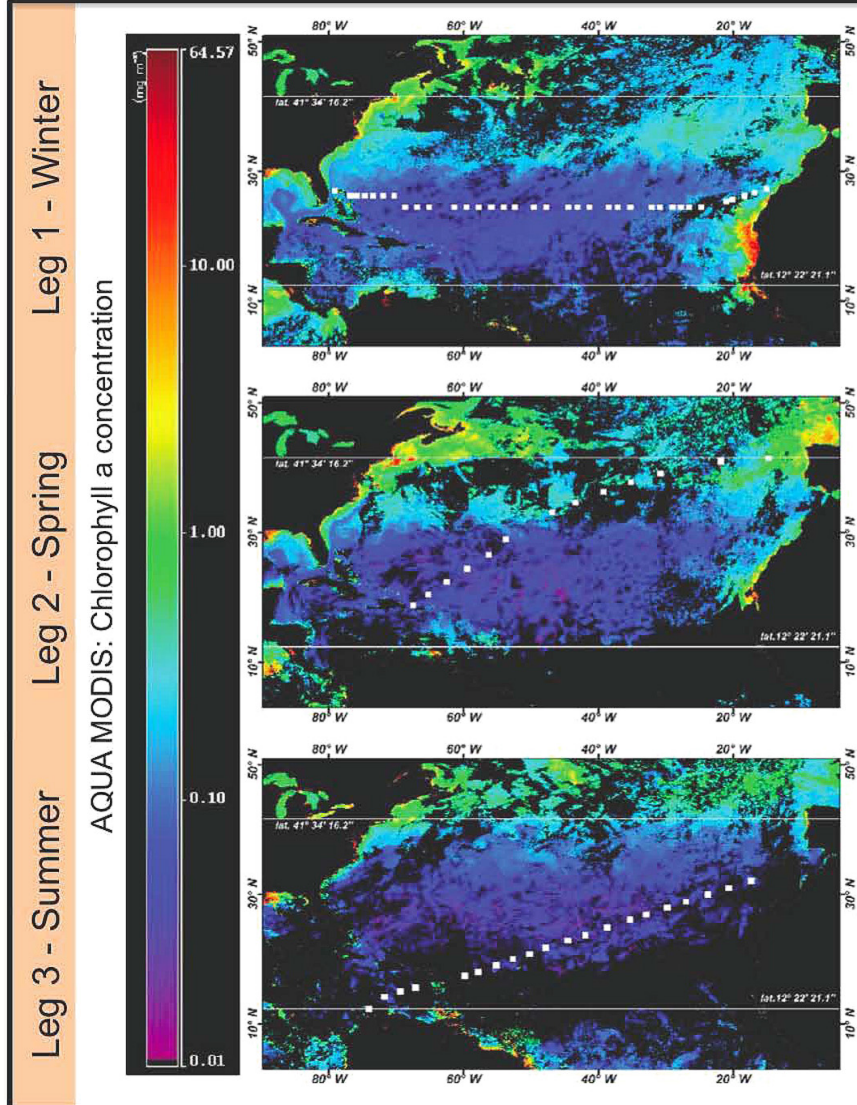

B

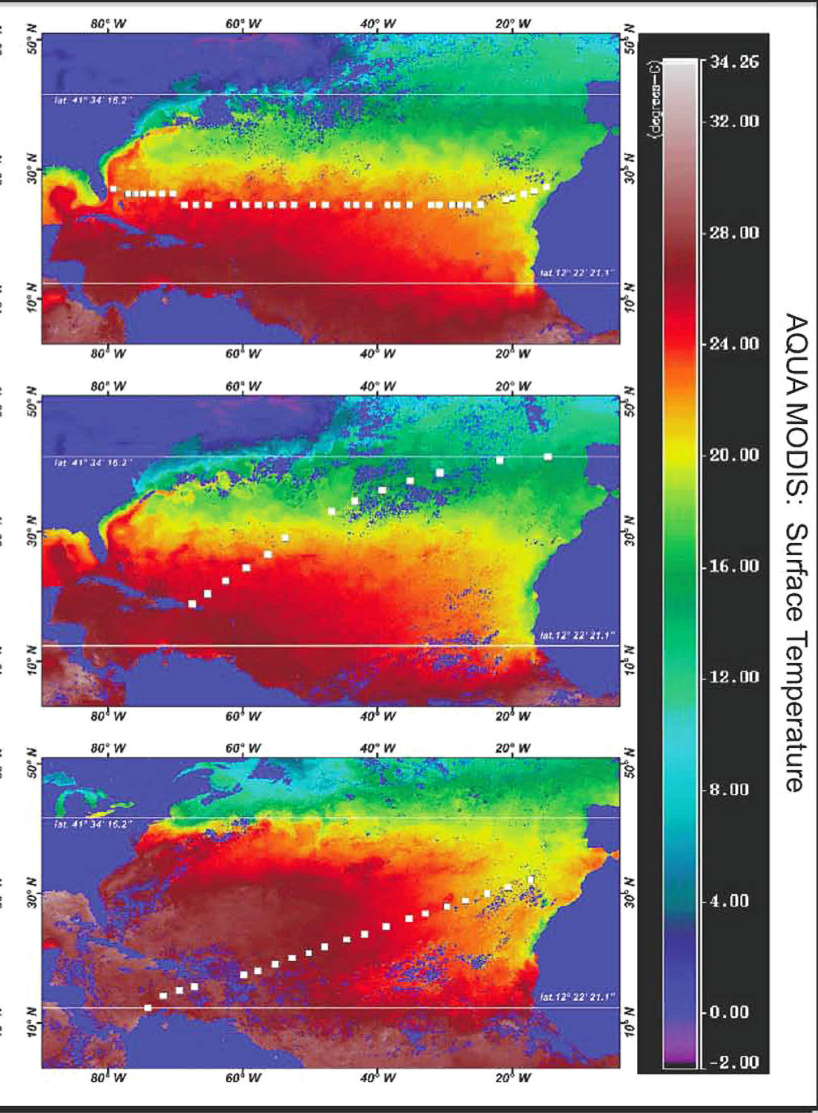

Figure 3. Satellite images showing 8-day-average chlorophyll $a$ (a) and surface water temperature (b) from the date of the central station sampled in winter, spring and summer cruise.

lower and similar mean integrated CR rates were observed in winter and summer (Table 2).

Integrated NCP rates varied greatly from net autotrophic $(\mathrm{NCP}>0)$ to net heterotrophic $(\mathrm{NCP}<0)$ across stations and seasons. However, the medians of integrated NCP showed a prevalence of autotrophic communities for winter, spring and summer cruises (Table 2). The mean $( \pm \mathrm{SE})$ integrated GPP / CR ratio confirmed an overall net autotrophic metabolism, with an overall mean of $1.39 \pm 0.27$ and no significant difference between cruises (Kruskal-Wallis test, $p>0.05)$. However, it is observed that the mean integrated GPP / CR ratio decreased from winter to summer (Table 2). Using integrated rates, autotrophic communities $(\mathrm{NCP}>0)$ represented about two-thirds of the total sampled stations (68.6, 61.5 and $65 \%$ for winter, spring and summer, respectively).

Net autotrophic communities were dominant across the 5 different Longhurst biogeochemical provinces (Longhurst, 1998, 2007) occupied during the three cruises (Table 3). Mean NCP and CR rates showed no significant differences between provinces (Kruskal-Wallis test, $p>0.05$ ), with the NASE province being the most autotrophic region and the
NASW region the most heterotrophic. However, mean GPP showed significant differences across provinces (KruskalWallis test, $p<0.05$ ), decreasing from the most productive regions NASE and CARB to NASW, NWCS and NATR, with the latter being the least productive region. The mean GPP / CR ratio, however, showed no significant differences between provinces and all showed medians around 1 (Table 3).

$\mathrm{CR}_{\mathrm{Chl} a}$ and $\mathrm{GPP}_{\mathrm{Chl} a}$ rates, binned by $1{ }^{\circ} \mathrm{C}$, increased with increasing seawater temperature during the spring cruise $\left(R^{2}=0.50, p=0.01 ; R^{2}=0.60, p=0.005\right.$, respectively). During winter, $\mathrm{CR}_{\mathrm{Chl} a}$ showed a significant temperature dependence (linear regression, $R^{2}=0.62, p=0.036$ ) but not $\operatorname{GPP}_{\mathrm{Chl} a}\left(R^{2}=0.32, p>0.05\right)$. Finally, in summer, $\mathrm{GPP}_{\mathrm{Chl} a}$ increased with temperature $\left(R^{2}=0.36, p=0.05\right)$ but there was no significant relation for $\mathrm{CR}_{\mathrm{Chl} a}\left(R^{2}=\right.$ $0.13, p>0.05$ ) (Fig. 4a, b). The activation energies (Ea) for $\mathrm{CR}_{\mathrm{Chl} a}$ were higher than those for $\mathrm{GPP}_{\mathrm{Chl} a}$ in winter and spring, but not in summer (Table 4). The experimental temperature manipulations showed a significant increase of $\mathrm{CR}_{\mathrm{Chl} a}$ with increasing temperature $\left(R^{2}=0.65, p=\right.$ 0.0009 ). The Ea derived from the experiments of temperature 
Table 2. Mean $( \pm$ SE), range, number of observations $(N)$ and median for the integrated metabolic rates (GPP, CR and NCP), GPP / CR ratio and the depth at which the DCM was located during each season.

\begin{tabular}{|c|c|c|c|c|}
\hline & & Winter (leg 1) & Spring (leg 2) & Summer (leg 3) \\
\hline $\begin{array}{l}\text { Integrated GPP } \\
\left(\mathrm{mmol} \mathrm{O}_{2} \mathrm{~m}^{-2} \mathrm{~d}^{-1}\right)\end{array}$ & $\begin{array}{l}\text { Mean } \pm \mathrm{SE} \\
\text { Range } \\
N \\
\text { Median }\end{array}$ & $\begin{array}{l}1.13 \pm 0.16 \\
0.19-3.29 \\
22 \\
0.87\end{array}$ & $\begin{array}{l}2.23 \pm 0.50 \\
0.4-6.60 \\
11 \\
2.07\end{array}$ & $\begin{array}{l}0.58 \pm 0.08 \\
0.33-1.13 \\
9 \\
0.50\end{array}$ \\
\hline $\begin{array}{l}\text { Integrated CR } \\
\left(\mathrm{mmol} \mathrm{O}_{2} \mathrm{~m}^{-2} \mathrm{~d}^{-1}\right)\end{array}$ & $\begin{array}{l}\text { Mean } \pm \mathrm{SE} \\
\text { Range } \\
N \\
\text { Median }\end{array}$ & $\begin{array}{l}1.20 \pm 0.21 \\
0.05-4.30 \\
21 \\
1.08\end{array}$ & $\begin{array}{l}2.27 \pm 0.55 \\
0.56-7.61 \\
12 \\
1.80\end{array}$ & $\begin{array}{l}1.14 \pm 0.31 \\
0.28-3.19 \\
9 \\
0.92\end{array}$ \\
\hline $\begin{array}{l}\text { Integrated NCP } \\
\left(\mathrm{mmol} \mathrm{O}_{2} \mathrm{~m}^{-2} \mathrm{~d}^{-1}\right)\end{array}$ & $\begin{array}{l}\text { Mean } \pm \mathrm{SE} \\
\text { Range } \\
N \\
\text { Median }\end{array}$ & $\begin{array}{l}0.27 \pm 0.23 \\
-3.71-4.95 \\
34 \\
0.28\end{array}$ & $\begin{array}{l}-0.18 \pm 0.60 \\
-5.53-3.80 \\
13 \\
0.26\end{array}$ & $\begin{array}{l}0.83 \pm 0.61 \\
-2.86-10.32 \\
19 \\
0.47\end{array}$ \\
\hline GPP / CR & $\begin{array}{l}\text { Mean } \pm \mathrm{SE} \\
\text { Range } \\
N \\
\text { Median }\end{array}$ & $\begin{array}{l}1.74 \pm 0.51 \\
0.14-11.13 \\
21 \\
1.16\end{array}$ & $\begin{array}{l}1.18 \pm 0.20 \\
0.27-2.35 \\
11 \\
1.17\end{array}$ & $\begin{array}{l}0.84 \pm 0.20 \\
0.10-1.74 \\
9 \\
0.8\end{array}$ \\
\hline $\begin{array}{l}Z_{\mathrm{DCM}} \\
(\mathrm{m})\end{array}$ & $\begin{array}{l}\text { Mean } \pm \mathrm{SE} \\
\text { Range } \\
N \\
\text { Mean } Z_{\mathrm{DCM}} \pm \mathrm{SE}\end{array}$ & $\begin{array}{l}119 \pm 5 \\
35-165 \\
35\end{array}$ & $\begin{array}{l}91 \pm 13 \\
20-156 \\
13 \\
114 \pm 4\end{array}$ & $\begin{array}{l}120 \pm 6 \\
71-161 \\
20\end{array}$ \\
\hline
\end{tabular}

Table 3. Mean $( \pm \mathrm{SE})$, range, number of observations $(N)$ and median of metabolic rates (GPP, CR, NCP) and GPP / CR ratio for the Longhurst biogeochemical provinces crossed in the study area.

\begin{tabular}{|c|c|c|c|c|c|}
\hline & & $\begin{array}{l}\text { GPP } \\
\left(\mathrm{mmol} \mathrm{O}_{2} \mathrm{~m}^{-3} \mathrm{~d}^{-1}\right)\end{array}$ & $\begin{array}{l}\mathrm{CR} \\
\left(\mathrm{mmol} \mathrm{O} \mathrm{m}^{-3} \mathrm{~d}^{-1}\right)\end{array}$ & $\begin{array}{l}\mathrm{NCP} \\
\left(\mathrm{mmol} \mathrm{O}_{2} \mathrm{~m}^{-3} \mathrm{~d}^{-1}\right)\end{array}$ & GPP / CR \\
\hline \multirow[t]{4}{*}{ NASE } & Mean $\pm \mathrm{SE}$ & $2.24 \pm 0.49$ & $1.86 \pm 0.23$ & $0.60 \pm 0.37$ & $2.92 \pm 1.59$ \\
\hline & Range & $0.00-11.42$ & $0.01-4.61$ & $63.77-7.86$ & $00.00-55.00$ \\
\hline & $N$ & 34 & 34 & 40 & 34 \\
\hline & Median & 0.82 & 1.46 & 0.23 & 1.15 \\
\hline \multirow[t]{4}{*}{ NATR } & Mean \pm SE & $0.90 \pm 0.09$ & $1.30 \pm 0.22$ & $0.08 \pm 0.23$ & $3.43 \pm 0.90$ \\
\hline & Range & $0.00-3.69$ & $0.01-16.25$ & $-16.12-5.66$ & $00.00-57.00$ \\
\hline & $N$ & 83 & 84 & 100 & 83 \\
\hline & Median & 0.66 & 0.76 & 0.10 & 0.99 \\
\hline \multirow[t]{4}{*}{ NASW } & Mean $\pm \mathrm{SE}$ & $1.53 \pm 0.21$ & $1.60 \pm 0.34$ & $0.00 \pm 0.27$ & $2.16 \pm 0.41$ \\
\hline & Range & $0.02-5.35$ & $0.06-8.17$ & $-6.63-2.76$ & $0.02-10.17$ \\
\hline & $N$ & 35 & 35 & 39 & 35 \\
\hline & Median & 1.00 & 0.92 & 0.31 & 1.33 \\
\hline \multirow[t]{4}{*}{ NWCS } & Mean $\pm \mathrm{SE}$ & $1.21 \pm 0.21$ & $0.87 \pm 0.22$ & $0.34 \pm 0.02$ & $1.49 \pm 0.19$ \\
\hline & Range & $0.81-1.51$ & $0.43-1.17$ & $0.31-0.38$ & $1.29-1.88$ \\
\hline & $N$ & 3 & 3 & 3 & 3 \\
\hline & Median & 1.31 & 1.00 & 0.34 & 1.31 \\
\hline \multirow[t]{4}{*}{ CARB } & Mean $\pm \mathrm{SE}$ & $2.27 \pm 1.31$ & $4.27 \pm 2.40$ & $0.22 \pm 2.20$ & $1.35 \pm 0.24$ \\
\hline & Range & $0.26-18.01$ & $0.09-28.42$ & $-27.27-27.20$ & $0.04-2.89$ \\
\hline & $N$ & 13 & 13 & 18 & 13 \\
\hline & Median & 1.00 & 1.04 & 0.22 & 1.12 \\
\hline
\end{tabular}


Table 4. Activation energy $(\mathrm{eV})$ as the slope of the regression and the parameters of the Arrhenius relationship between the natural logarithm of chlorophyll $a$-specific metabolic rates $\left(\mathrm{mmol} \mathrm{O}_{2} \mathrm{mg} \mathrm{Chl} a^{-1} \mathrm{~d}^{-1}\right)$ binned by $1^{\circ} \mathrm{C}$ and inverted temperature $(1 / k T)$ for each season and the temperature manipulation experiments in spring.

\begin{tabular}{llllllll}
\hline & Temperature range & Rate & Intercept \pm SE & Slope \pm SE & $R^{2}$ & $p$ & $n$ \\
\hline Winter (leg 1) & $19.3-24.8^{\circ} \mathrm{C}$ & GPP & $29.94 \pm 18.17$ & $-0.72 \pm 0.46$ & 0.32 & 0.18 & 7 \\
& & CR & $55.73 \pm 18.90$ & $-1.37 \pm 0.48$ & 0.62 & $0.036^{*}$ & 7 \\
Spring (leg 2) & $14.3-25.7^{\circ} \mathrm{C}$ & GPP & $58.52 \pm 15.16$ & $-1.41 \pm 0.38$ & 0.60 & $0.005^{*}$ & 11 \\
& & CR & $72.16 \pm 23.31$ & $-1.74 \pm 0.59$ & 0.50 & $0.01^{*}$ & 11 \\
Summer (leg 3) & $17-29{ }^{\circ} \mathrm{C}$ & GPP & $58.12 \pm 25.10$ & $-1.44 \pm 0.64$ & 0.36 & $0.05^{*}$ & 11 \\
& & CR & $50.52 \pm 28.89$ & $-1.23 \pm 0.74$ & 0.13 & 0.23 & 11 \\
Experimental temperature manipulation & $14-30^{\circ} \mathrm{C}$ & $\mathrm{CR}$ & $67.60 \pm 14.43$ & $-1.64 \pm 0.36$ & 0.65 & $0.0009^{*}$ & 13 \\
\hline
\end{tabular}

dependence of $\mathrm{CR}_{\mathrm{Chl} a}(1.64 \pm 0.36 \mathrm{eV})$ was not significantly different from those derived from in situ data (Table 4, Fig. 5), demonstrating consistency between experimental and in situ relationships. Indeed, use of the Arrhenius linear relationship derived experimentally from temperature manipulations to predict the in situ values yields predicted values consistent with the observed ones, with the slope of the relationship between observed and predicted $\mathrm{CR}_{\mathrm{Chl} a}$ not differing significantly from 1 (linear regression model II equation, slope $( \pm \mathrm{SE})=1.32 \pm 0.23)$.

\section{Discussion}

Plankton metabolism showed considerable variation along the longitudinal sections examined in this study of the subtropical North Atlantic Ocean. Plankton metabolism had been poorly studied in the western basin of the North Atlantic Ocean, as almost all rates reported for the northern subtropical Atlantic are derived from the eastern basin (Reguadie-deGioux and Duarte 2012), except a few studies derived from the Bermuda Atlantic Time-series Study (BATS) in the Sargasso Sea (Williams et al., 2013). Indeed, the western and eastern basins, separated by the Mid-Atlantic Ridge, differ significantly in key physical, chemical and biological properties, such as water temperature, chlorophyll $a$ concentrations and salinity (Sathyendranath et al., 1995; Li and Harrison, 2001). Our results show a longitudinal eastward decreasing temperature gradient from warmer superficial waters in the western basin to a cooler eastern basin, with colder areas supporting higher chlorophyll $a$ concentrations. The lowest chlorophyll $a$ concentrations were found in the oligotrophic subtropical North Atlantic Gyre region, and the highest rates corresponded to waters of the northwest African upwelling (González et al., 2002). The chlorophyll $a$ concentration values were on average $\left(0.22 \pm 0.02 \mathrm{mg} \mathrm{Chl} a \mathrm{~m}^{-3}\right)$ within the ranges previously reported for the North and South Atlantic subtropical gyres (González et al., 2002; Teira et al., 2005).

Here we report a high temporal and spatial variability of metabolic rates in the subtropical North Atlantic Ocean. Such variability can be due to atmospheric forcing (i.e., North
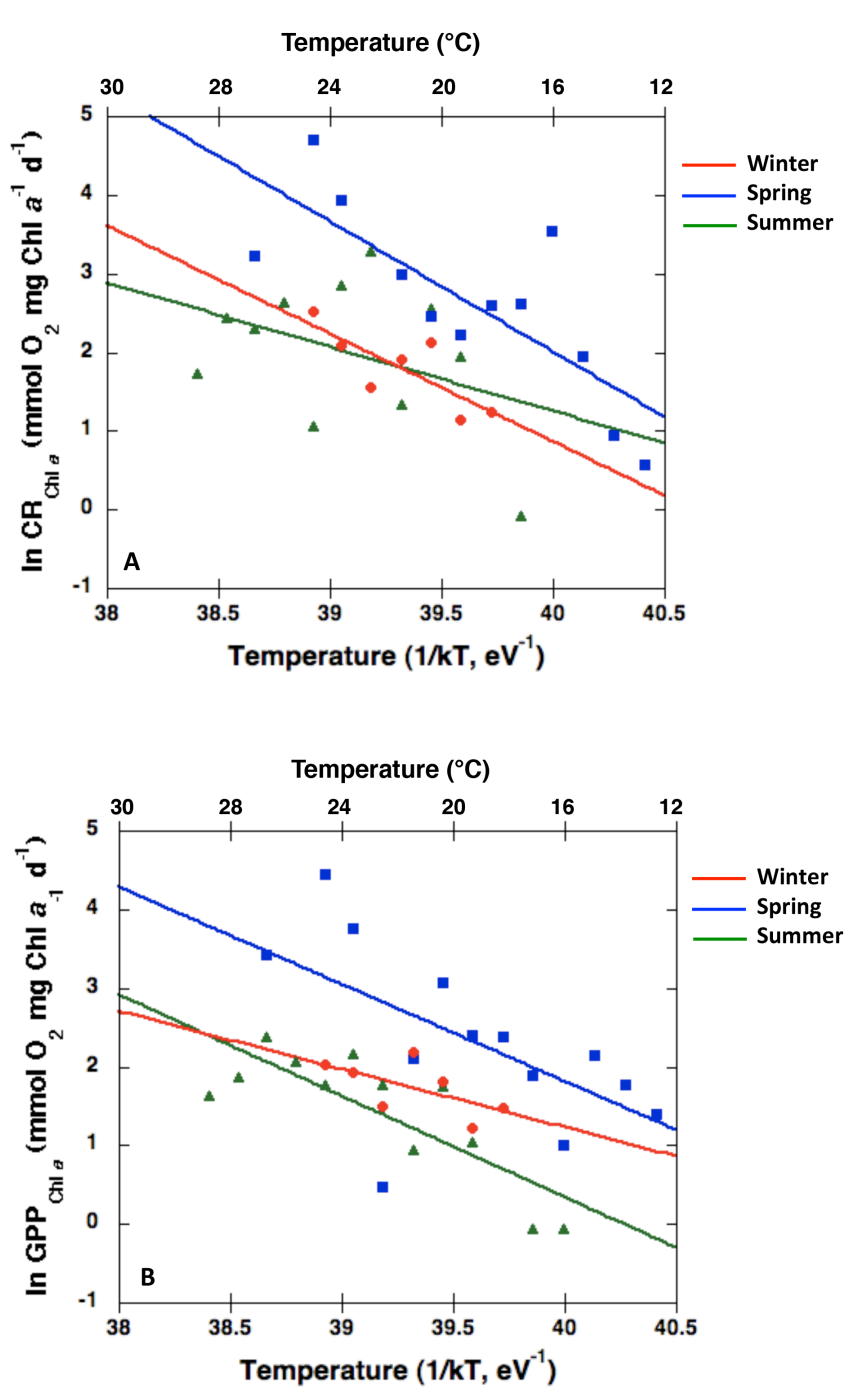

Figure 4. Arrhenius plots showing the relationship between $\mathrm{Chl} a$ specific average rates (a) $\mathrm{CR}_{\mathrm{Chl} a}$ and (b) $\mathrm{GPP}_{\mathrm{Chl} a}$ within $1{ }^{\circ} \mathrm{C}$ bins and the inverted water temperature $(1 / k T$, where $k$ is the Boltzmann's constant, $8.617 \times 10^{-5} \mathrm{eV} \mathrm{k}^{-1}$, and $T$ is the water temperature in ${ }^{\circ} \mathrm{K}$ ) for legs 1,2 and 3 . 


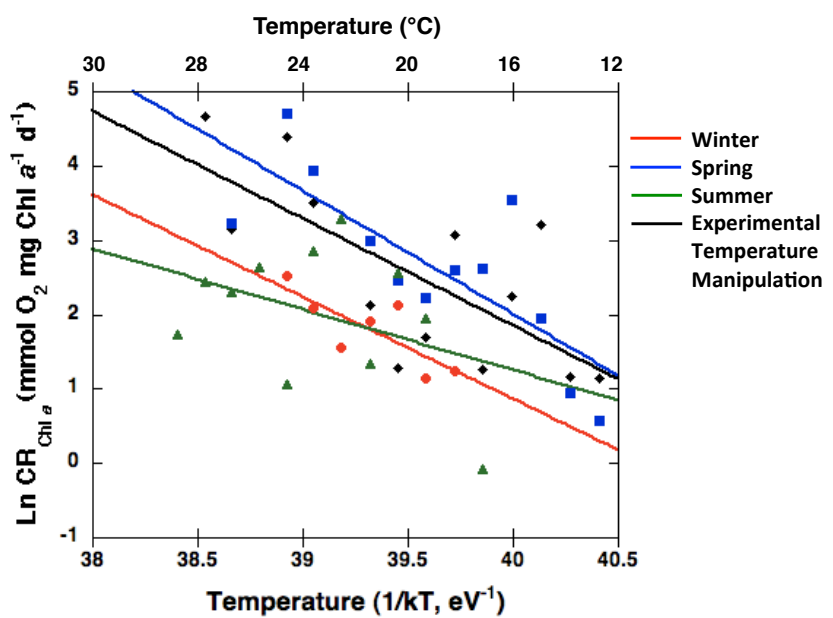

Figure 5. Arrhenius plot showing the relationship between average $\mathrm{Chl} a$-specific respiration rate within $1^{\circ} \mathrm{C}$ bins and the inverted water temperature $(1 / k T$, where $k$ is the Boltzmann's constant, $8.617 \times 10^{-5} \mathrm{eV} \mathrm{k}^{-1}$, and $T$ is the water temperature in ${ }^{\circ} \mathrm{K}$ ) for experimental temperature manipulations conducted during the spring cruise as well as Arrhenius plots for winter, spring and summer cruises for comparison.

Atlantic Oscillation), as interannual variability in $p \mathrm{CO}_{2}$ correlated with temperature and mixed-layer depth anomalies, can affect the nutrient supply to the euphotic zone (Gruber et al., 2002). Physical forcing mechanisms such as mesoscale instabilities can act as important sources of organic carbon (González et al., 2001) and nutrients (Garçon et al., 2001) to the pelagic ecosystems in oligotrophic areas. Also, intrinsic factors, such as changes in phytoplankton community structure and trophic dynamics (Serret et al., 2009) can influence the variability of plankton community metabolic rates. High temporal and spatial variability of metabolic rates between stations and cruises has been observed in the subtropical North Atlantic Ocean, with higher GPP and CR rates in spring (González et al., 2002) and in the eastern basin, and lower metabolic rates in winter and summer and in the western basin. During the spring season in the mid-latitude North Atlantic Ocean, the westerly winds decrease and the solar radiation increase, supporting the conditions for a phytoplankton bloom (Harrison et al., 2001). Depletion of nutrients with higher stratification of the water column in summer leads to a decrease in productivity and metabolic rates (González et al., 2001), with a secondary bloom developing with the onset of mixing during fall and a subsequent decrease of photosynthetic rates with the reduction of solar radiation during winter (Longhurst, 1998).

The subtropical North Atlantic Ocean showed a net metabolic balance in this study, with a prevalence of autotrophy in $66 \%$ of the communities. The prevalence of autotrophic conditions in the three cruises conducted is in contrast to previous reports of a prevalence of heterotrophy in oligotrophic gyres (del Giorgio et al., 1997;
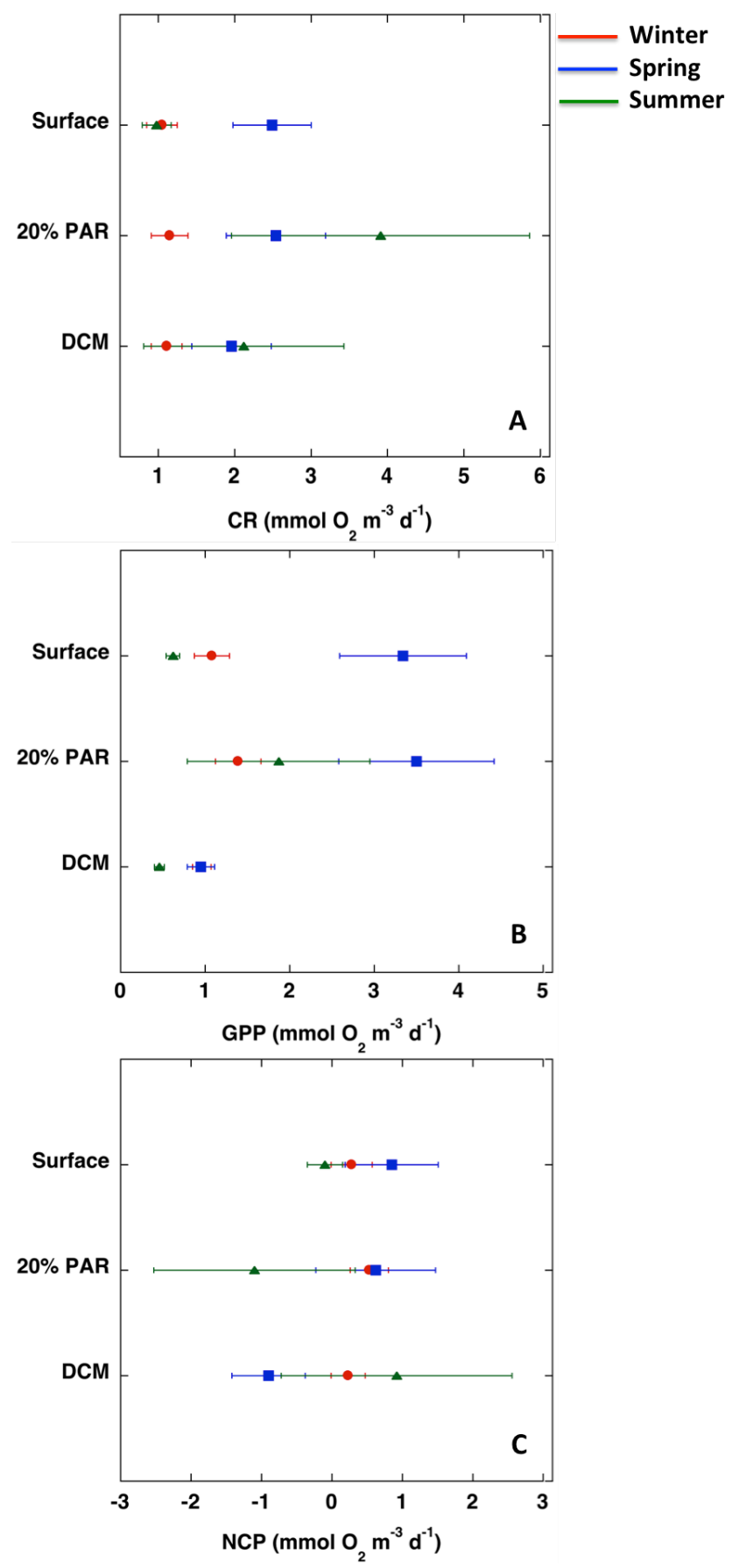

Figure 6. Mean $\pm \mathrm{SE}$ for (a) community respiration (CR), (b) gross primary production (GPP) and (c) net community production (NCP) $\left(\mathrm{mmol} \mathrm{O}_{2} \mathrm{~m}^{-3} \mathrm{~d}^{-1}\right)$ for each season (winter, spring and summer) at the three sampled depths (surface, $20 \%$ PAR and DCM).

Duarte and Agustí, 1998; Duarte et al., 2013) and for the subtropical North Atlantic Ocean (Duarte et al., 2001; González et al., 2002; Serret et al., 2002, 2006; Morán et al., 2004; Aranguren-Gassis et al., 2011). However, some studies have also shown balanced metabolism (Williams, 1998; 
Aranguren-Gassis and Serret, 2012) or a prevalence of autotrophic communities (Kähler et al., 2010), leading to challenges in the view that oligotrophic regions of the ocean support heterotrophic plankton communities (Williams et al., 2013). These contrasting results may be due to interannual variability in ocean metabolism, which has not been assessed as of yet, but has been shown to be important in driving variability in satellite-based primary production estimates (Behrenfeld and Falkowski, 1997) and in the inorganic carbon cycle (Gruber et al., 2002). Alternatively, previous assessments were all based on the eastern basin of the subtropical North Atlantic Ocean, which suggests possible differences across basins. The eastern basin of the North Atlantic receives allochthonous organic carbon inputs, both as production exported from the North African upwelling (Pelegrí et al., 2005) and atmospheric inputs (Dachs et al., 2005), which must, therefore, support balanced or autotrophic metabolism. Sources of allochthonous organic carbon and nutrients into the western basin are less evident, but mainly come from large rivers such as the Amazon and Orinoco that discharge $70140 \mathrm{~km}^{3} \mathrm{yr}^{-1}$ of freshwater into the Atlantic western basin (Franzinelli and Potter, 1983; Lewis et al., 1990). An autotrophic status suggests either enhanced GPP or reduced inputs of allochthonous organic carbon (reduce $\mathrm{CR}$ ), both contributing to positive NCP.

The metabolic theory of ecology (MTE, Gillooly et al., 2001; Brown et al., 2004) predicts an increase in the metabolic rates with increasing temperature, confirmed for plankton communities (López-Urrutia et al., 2006; Regaudiede-Gioux and Duarte, 2012). Our results confirm these expectations and show a clear temperature dependence of standardized chlorophyll $a$ metabolic rates (GPP and CR) along the temperature range measured $\left(14\right.$ to $\left.29^{\circ} \mathrm{C}\right)$. Metabolic responses to temperature are dependent on the availability of other resources, such as light, nutrients or organic matter, to support autotrophic or heterotrophic metabolism (LópezUrrutia and Morán, 2007). Our results show that about 50\% of the variability in respiration rates among plankton communities in the subtropical Atlantic Ocean can be accounted for by temperature differences, confirmed by the results of our experimental temperature manipulations. This suggests that whereas other resources may contribute to explain the $50 \%$ of the variability in respiration rates that cannot be accounted for by temperature differences, the availability of resources is still sufficient to leave scope for metabolic control by temperature. The activation energy values for GPP and CR were 2 to 4.5 -fold higher than those reported by Regaudie-de-Gioux and Duarte, $2012\left(\mathrm{Ea}_{\mathrm{GPP}}=0.32 \mathrm{eV}\right.$ and $\left.\mathrm{Ea}_{\mathrm{CR}}=0.66 \mathrm{eV}\right)$, measured across a much wider temperature range $\left(0\right.$ to $\left.29^{\circ} \mathrm{C}\right)$ across the ocean. The empirical activation energies for $\mathrm{CR}$ reported in this study showed consistently higher values than those derived for Atlantic communities by López-Urrutia et al. (2006) $\left(\mathrm{Ea}_{\mathrm{CR}}=0.65 \mathrm{eV}\right)$ and Regaudie-de-Gioux and Duarte (2012) $\left(\mathrm{Ea}_{\mathrm{CR}}=0.92 \mathrm{eV}\right)$, those inferred from ETS activity (Arístegui and Montero,
1995; $\mathrm{Ea}_{\mathrm{CR}}=0.7044 \mathrm{eV}$ ), and those observed for respiration rates in aquatic ecosystems in general (Yvon-Durocher et al., 2012; $\mathrm{Ea}_{\mathrm{CR}}=0.65 \mathrm{eV}$ ). The results presented here also confirm a general higher activation energy for CR than GPP in the subtropical North Atlantic Ocean, consistent with expectations from metabolic theory (Brown et al., 2004; Harris et al., 2006; López-Urrutia et al., 2006) and previous global analyses (Regaudie-de-Gioux and Duarte, 2012). However, the experimental $\mathrm{Ea}_{\mathrm{CR}}$, at $1.64 \pm 0.36 \mathrm{eV}$, was higher, although not significantly so, than the average $(1.45 \pm 0.6 \mathrm{eV})$ determined through comparative analyses across communities, suggested that the temperature dependence of plankton communities exposed to short-term temperature increase overestimates that of communities pre-adapted to different temperature regimes. Most importantly, our results show a remarkable consistency between activation energies for respiration rates derived from the comparative analysis of in situ rates, and those derived from experimental manipulation of temperature. Hence, the temperature dependence of planktonic metabolism reported here helps to explain spatial and seasonal patterns in planktonic metabolism in the open ocean. The North Atlantic Ocean constitutes the largest ocean sink for atmospheric $\mathrm{CO}_{2}$ in the Northern Hemisphere (Gruber et al., 2002), storing $23 \%$ of the global oceanic anthropogenic $\mathrm{CO}_{2}$, despite covering only $15 \%$ of the global ocean area (Sabine et al., 2004). Long-term trends indicate that the subtropical gyre of the North Atlantic Ocean is, at present, acting as a significant sink for anthropogenic $\mathrm{CO}_{2}$ (Bates et al., 2002). However, the results presented here show that the metabolic balance of the subtropical North Atlantic Ocean may be highly sensitive to warming. Assuming the forecasted ocean warming of $1-3^{\circ} \mathrm{C}$ by the end of the century (IPCC, 2007), our finding of an increase in respiration rates with warming suggests that the role of plankton communities in the subtropical North Atlantic communities as significant $\mathrm{CO}_{2}$ sinks may be weakened substantially or even revert to becoming $\mathrm{CO}_{2}$ sources to the atmosphere in the future. This consistency confirms the predictive power of the metabolic theory of ecology to predict the responses of plankton community metabolism to foretell negative feedbacks of warming on the $\mathrm{CO}_{2}$ sink capacity of marine biota (López-Urrutia et al., 2006), possibly shifting communities (Lomas and Bates, 2004) toward a higher prevalence of heterotrophy across the subtropical North Atlantic. 
Acknowledgements. This is a contribution to the Malaspina Expedition 2010, funded by the INGENIO 2010 CONSOLIDER program (ref. CDS2008-00077) of the Spanish Ministry of Economy and Competitiveness. We thank the captains and crews of R/V Sarmiento de Gamboa and R/V Hespérides and the UTM for their help onboard and technical support, M. Fuster for help with mapping and satellite imagery, and the participants of the Malaspina Expedition and Buque Escuela projects for providing CTD data and general support. L. S. García-Corral was supported by a JAE Pre-doc fellowship from the Spanish National Research Council (CSIC) and the BBVA Foundation, Spain.

Edited by: G. Herndl

\section{References}

Agustí, S., Regaudie-de-Gioux, A., Arrieta, J. M., and Duarte, C. M.: Consequences of UV-enhanced community respiration for plankton metabolic balance, Limnol. Oceanogr., 59, 5-15, 2014.

Aranguren-Gassis, M., Serret, P., Fernández, E., Herrera, J. L., Domínguez, J. F., Pérez, V., and Escanez, J.: Production and respiration control the marine microbial metabolic balance in the eastern North Atlantic subtropical gyre, Deep-Sea Res. Pt. I, 58, 768-775, 2011.

Aranguren-Gassis, M. and Serret, P.: Balanced plankton net community metabolism in the oligotrophic North Atlantic subtropical gyre from Lagrangian observations, Deep-Sea Res. Pt. I, 68, 116-122, 2012.

Arístegui, J. and Montero, M. F.: The relationship between community respiration and ETS activity in the ocean, J. Plankton Res., 17, 1563-1571, 1995.

Bates, N. R., Pequignet, A. C., Johnson, R. J., and Gruber, N.: A short-term sink for atmospheric $\mathrm{CO}_{2}$ in subtropical mode water of the North Atlantic Ocean, Nature, 420, 489-493, 2002.

Behrenfeld, M. J. and Falkowski, P. G.: Photosynthetic rates derived from satellite-based chlorophyll concentration, Limnol. Oceanogr., 42, 1-20, 1997.

Brown, J. H., Gillooly, J. F., Allen, A. P., Savage, V. M., and West, G. B.: Toward a metabolic theory of ecology, Ecology, 85, 17711789, 2004.

Carritt, D. E. and Carpenter, J.: Comparison and evaluation of currently employed modifications of winkler method for determining dissolved oxygen in seawater - a Nasco Report, J. Mar. Res., 24, 286-318, 1966.

Dachs, J., Calleja, M. L., Duarte, C. M., Del Vento, S., Turpin, B., Polidori, A., and Agustí, S.: High atmosphere-ocean exchange of organic carbon in the NE subtropical Atlantic, Geophys. Res. Lett., 32, L21807, doi:10.1029/2005GL023799, 2005.

Del Giorgio, P. A., Cole, J. J., and Cimbleris, A.: Respiration rates in bacteria exceed phytoplankton production in unproductive aquatic systems, Nature, 385, 148-151, 1997.

Dessier, A. and Donguy, J. R.: The sea surface salinity in the tropical Atlantic between $10 \mathrm{~S}$ and $30 \mathrm{~N}$ - Seasonal and interannual variations (1977-1989), Deep-Sea Res. Pt. I, 41, 81-100, 1994.

Duarte, C. M. and Agustí, S.: The $\mathrm{CO}_{2}$ balance of unproductive aquatic ecosystems, Science, 281, 234-236, 1998.

Duarte, C. M., Agustí, S., Arístegui, J., González, N., and Anadón, R.: Evidence for a heterotrophic subtropical northeast Atlantic, Limnol. Oceanogr., 46, 425-428, 2001.
Duarte, C. M., Agustí, S., and Regaudie-de-Gioux, A.: The role of marine biota in the metabolism of the biosphere, 39-53, in: The role of marine biota in the functioning of the biosphere, edited by: Duarte, C. M., Fundación BBVA, Bilbao, 2011.

Duarte, C. M., Agustí, S., Wassmann, P., Arrieta, J. M., Alcaraz, M., Coello, A., Marbà, N., Hendriks, I. E., Holding, J., GarcíaZarandona, I., Kritzberg, E., and Vaqué, D.: Tipping elements in the Arctic marine ecosystem, AMBIO, 41, 44-55, 2012.

Duarte, C. M., Regaudie-de-Gioux, A., Arrieta, J. M., DelgadoHuertas, A., and Agustí, S.: The oligotrophic ocean is heterotrophic, Annu. Rev. Mar. Sci. 5, 551-569, 2013.

Estrada, M.: Determinación fluorimétrica de la concentración de clorofila a, in: Expedición de circunnavegación Malaspina 2010, edited by: Moreno-Ostos, E., Cambio global y exploración de la biodiversidad del océano, Libro blanco de métodos y técnicas de trabajo oceanográfico, CSIC, Madrid, 399-406, 2012.

Franzinelli, E. and Potter, P.: Petrology, chemistry and texture of modern river sands, Amazon River system, J. Geol., 78, 12031232, 1983.

Garçon, V. C., Oschlies, A., Doney, S. C., McGillicuddy, D., and Waniek, J.: The role of mesoscale variability on plankton dynamics in the North Atlantic, Deep-Sea Res. Pt. II, 48, 2199-2226, 2001.

Gillooly, J. F., Brown, J. H., West, G. B., Savage, V. M., and Charnov, E. L.: Effects of size and temperature on metabolic rate, Science, 293, 2248-2251, 2001.

González, N., Anadón, R., Mouriño, B., Fernández, E., Sinha, B., Escánez, J., and De Armas, D.: The metabolic balance of the planktonic community in the North Atlantic Subtropical Gyre: The role of mesoscale instabilities, Limnol. Oceanogr., 46, 946952, 2001.

González, N., Anadón, R., and Marañón, E.: Large-scale variability of planktonic net community metabolism in the Atlantic Ocean: importance of temporal changes in oligotrophic subtropical waters, Mar. Ecol.-Prog. Ser., 233, 21-30, 2002.

Gruber, N., Keeling, C. D., and Bates, N. R.: Interannual variability in the North Atlantic Ocean carbon sink, Science, 298, 2374 2378, 2002.

Harris, L. A., Duarte, C. M., and Nixon, S. W.: Allometric laws and prediction in estuarine and coastal ecology, Estuar. Coasts, 29, 340-344, 2006.

Harrison, W., Aristegui, J., Head, E. J., Li, W. K., Longhurst, A., and Sameoto, D.: Basin-scale variability in plankton biomass and community metabolism in the sub-tropical North Atlantic Ocean, Deep-Sea Res. Pt. II, 48, 2241-2269, 2001.

IPCC 2007 Climate change 2007: the physical sciences basis, in: Contribution of Working Group I to the fourth assessment report of the Intergovernmental Panel on Climate Change, edited by: Parry, M. L., Canziani, O. F., Palutikof, J. P., van der Linden, P. J., and C. E. Hanson, 7-22, Cambridge, UK, Cambridge University Press, 2007.

Kähler, P., Oschlies, A., Dietze, H., and Koeve, W.: Oxygen, carbon, and nutrients in the oligotrophic eastern subtropical North Atlantic, Biogeosciences, 7, 1143-1156, doi:10.5194/bg-7-11432010, 2010.

Levitus, S., Antonov, J. I., Boyer, T. P., and Stephens, C.: Warming of the World Ocean, Science, 287, 2225-2229, 2000. 
Levitus, S., Antonov, J., and Boyer, T.: Warming of the world ocean, 1955-2003, Geophys. Res. Lett., 32, L02604, doi:10.1029/2004GL021592, 2005.

Lewis, W. M., Weibezahn, F. H., Saunders III., J. F., and Hamilton, S. K.: The Orinoco River as an ecological system, Interciencia, 15, 346-357, 1990.

Li, W. K. and Harrison, W.: Chlorophyll, bacteria and picophytoplankton in ecological provinces of the North Atlantic, Deep-Sea Res. Pt. II, 48, 2271-2293, 2001.

Lomas, M. W. and Bates, N. R.: Potential controls on interannual partitioning of organic carbon during the winter/spring phytoplankton bloom at the Bermuda Atlantic Time-series Study (BATS) site, Deep-Sea Res. Pt. I, 51, 1619-1636, 2004.

Longhurst, A.: Ecological Geography of the Sea, Academic Press, San Diego, CA, 1998.

Longhurst, A.: Ecological Geography of the Sea, 2nd ed., Academic Press, San Diego, CA, 2007.

López-Urrutia, Á. and Morán, X. A. G.: Resource limitation of bacterial production distorts the temperature dependence of oceanic carbon cycling, Ecology, 88, 817-822, 2007.

López-Urrutia, A., San Martin, E., Harris, R. P., and Irigoien, X.: Scaling the metabolic balance of the oceans, P. Natl. Acad. Sci. USA, 103, 8739-8744, 2006.

Marañón, E., Holligan, P. M., Varela, M., Mouriño, B., and Bale, A. J.: Basin-scale variability of phytoplankton biomass, production and growth in the Atlantic Ocean, Deep-Sea Res. Pt. I, 47, 825857,2000 .

Marshall, J., Kushnir, Y., Battisti, D., Chang, P., Czaja, A., Dickson, R., and Visbeck, M.: North Atlantic climate variability: phenomena, impacts and mechanisms, Int. J. Climatol., 21, 1863-1898, 2001.

Morán, X., Fernández, E., and Pérez, V.: Size-fractionated primary production, bacterial production and net community production in subtropical and tropical domains of the oligotrophic NE Atlantic in autumn. Mar. Ecol.-Prog. Ser., 274, 17-29, 2004.

Oudot, C., Gerard, R., Morin, P., and Gningue, I.: Precise shipboard determination of dissolved-oxygen (Winkler Procedure) for productivity studies with a commercial system, Limnol. Oceanogr., 33, 146-150, 1988.

Pelegrí, J. L., Arístegui, J., Cana, L., González-Dávila, M., Hernández-Guerra, A., Hernández-León, S., and SantanaCasiano, M.: Coupling between the open ocean and the coastal upwelling region off northwest Africa: water recirculation and offshore pumping of organic matter, J. Mar. Syst., 54, 3-37, 2005.
Regaudie-de-Gioux, A. and Duarte, C. M.: Temperature dependence of planktonic metabolism in the ocean, Global Biogeochem Cy., 26, 1-10, 2012.

Regaudie-de-Gioux, A. and Duarte, C. M.: Global patterns in oceanic planktonic metabolism, Limnol. Oceanogr., 58, 977986, 2013.

Robinson, C. and Williams, P. J. le B.: Respiration and its measurement in surface marine waters, in Respiration in Aquatic Ecosystems, edited by: del Giorgio, P. and Williams, P. J. le B., 148-181, Oxford Univ. Press, Cambridge, UK, 2005.

Sabine, C. L., Feely, R. A., Gruber, N., Key, R. M., Lee, K., Bullister, J. L., and Rios, A. F.: The oceanic sink for anthropogenic $\mathrm{CO}_{2}$, Science, 305, 367-371, 2004.

Sathyendranath, S., Longhurst, A., Caverhill, C. M., and Platt, T.: Regionally and seasonally differentiated primary production in the North Atlantic, Deep-Sea Res. Pt. I, 42, 1773-1802, 1995.

Serret, P., Fernández, E., and Robinson, C.: Biogeographic differences in the net ecosystem metabolism of the open ocean, Ecology., 83, 3225-3234, 2002.

Serret, P., Fernandez, E., Robinson, C., Woodward, E. M. S., and Perez, V.: Local production does not control the balance between plankton photosynthesis and respiration in the open Atlantic Ocean, Deep-Sea Res. Pt. I, 53, 1611-1628, 2006.

Serret, P., Robinson, C., Fernández, E., Teira, E., Tilstone, G., and Pérez, V.: Predicting plankton net community production in the Atlantic Ocean, Deep-Sea Res. Pt. II, 56, 941-953, 2009.

Teira, E., Mourino, B., Maranon, E., Perez, V., Pazo, M., Serret, P., Dearmas, D., Escanez, J., Woodward, E., and Fernandez, E.: Variability of chlorophyll and primary production in the Eastern North Atlantic Subtropical Gyre: potential factors affecting phytoplankton activity, Deep-Sea Res. Pt. I, 52, 569-588, 2005.

Williams, P. J.: The balance of plankton respiration and photosynthesis in the open oceans, Nature, 394, 55-57, 1998.

Williams, P. J., Quay, P. D., Westberry, T. K., and Behrenfeld, M. J. :The Oligotrophic Ocean Is Autotrophic, Annu. Rev. Mar. Sci., 5, 535-549, 2013.

Yentsch, C. S. and Menzel, D. W.: A method for determination of chlorophyll and phaeophytin by fluorescence, Deep-Sea Res. Pt. I, 10, 221-231, 1963.

Yvon-Durocher, G., Caffrey, J. M., Cescatti, A., Dossena, M., Giorgio, P. Del, Gasol, J. M., Montoya, J. M., Pumpanen, J., Staehr, P. A., Trimmer, M., Woodward, G., and Allen, A. P.: Reconciling the temperature dependence of respiration across timescales and ecosystem types, Nature, 487, 472-476, 2012. 